\title{
ANALISIS PENGARUH KUALITAS PELAYANAN KEPUASAN HARGA TERHADAP KEPUTUSAN PEMBELIAN SWALAYAN NABILA YOGYAKARTA
}

\author{
Mega Ria Dewanto \\ Dewa_122yproject@hotmail.com \\ Universitas Ahmad Dahlan \\ Salamatun Asakdiyah \\ Salamatun_2009@yahoo.com \\ Universitas Ahmad Dahlan
}

\begin{abstract}
ABSTRAK
Retail business in Indonesia has developed quite rapidly in the last few years with various forms and types. Competition in the retail or retail business which is currently increasingly fierce forces retail or retail business entrepreneurs to compete with each other to try to attract the attention of consumers. This study aims to determine and analyze the variables of service quality, satisfaction and price partially or jointly with purchasing decisions at the Nabila supermarket in Yogyakarta. In this study the sample used was a portion of Nabila Yogyakarta self-service consumers using Purposive Sampling techniques totaling 100 people. The analysis technique used is multiple linear regression analysis. The results of this study are that Service Quality has a positive and significant influence on the purchasing decisions of Nabila Supermarket customers in Yogyakarta with a regression coefficient of 0.409 (positive) and a tcount of 3.351 and a probability of error $(\mathrm{p})=0.001$. Satisfaction variable has a positive and significant influence on the purchasing decisions of Nabila Supermarket customers in Yogyakarta with a regression coefficient of 0.249 (positive) and a tcount of 2.466 and $p=0.015$. Price variable has a positive and significant influence on customer purchasing decisions in Nabila Yogyakarta with a regression coefficient of 0.336 (positive) and the significance test for the coefficient obtained is 3.751 and $\mathrm{p}=0.000$. Variable Service Quality, Satisfaction and Price simultaneously influence the customer purchasing decisions on users of Yogyakarta Nabila Supermarket with F statistics obtained by Fcount of 17.961 and the probability of error $(\mathrm{p})=0,000$.
\end{abstract}

Keyword: Service Quality, Satisfaction, Price and Purchasing Decisions.

\begin{tabular}{l}
\hline Usaha bisnis ritel di Indonesia \\
perkembangan cukup \\
mengalami tahun terakhir ini \\
pesat \\
pada beberapa tahun \\
dengan berbagai macam bentuk dan \\
jenisnya. Untuk menjadikan usaha ritel \\
berhasil sukses, maka pihak \\
manajemen \\
harus mempunyai strategi - strategi \\
khusus dalam menjalankannya. Ritel \\
adalah \\
usaha yang menjual produk /
\end{tabular}

dagangan kebutuhan rumah tangga, termasuk produk kebutuhan sehari-hari yang menggunakan sistem swalayan (konsumen mengambil barang / produk itu sendiri).

Barang atau produk tersebut dapat berupa kebutuhan primer / pokok masyarakat maupun kebutuhan sekunder. Penyedia kebutuhan seharihari

(consumer goods) banyak disediakan oleh toko - toko kelontong maupun supermarket. Konsumen dari supermarket merupakan masyarakat 
pada

umumnya

yang terdiri dari semua usia baik tua maupun muda, yang kebanyakan bertempat tinggal di sekitar toko atau supermarket tersebut. Dalam satu daerah tertentu sering kali banyak sekali bermunculan bermacan macam jenis supermarket. Persaingan dalam bisnis eceran atau ritel yang sekarang ini semakin ketat memaksa para pengusaha bisnis eceran atau ritel saling bersaing untuk berusaha menarik perhatian konsumen.

Menurut $\begin{array}{r}\text { Tjiptono } \\ \text { kaysumen }\end{array}$
mempertimbangkan
faktor seperti citra merek, kepuasan,
layanan, nilai dan lebih sensitif terhadap

harga. Kebanyakan pelanggan, baru melakukan evaluasi bila sudah ada pengalaman kurang enak meskipun hanya masalah kecil. Kualitas pelayanan juga merupakan faktor penting dalam pemasaran. Parasuraman, et al. (2008) mendefinisikan kualitas pelayanan sebagai dasar bagi pemasaran jasa, karena inti produk yangdipasarkan adalah suatu kinerja (yang berkualitas), dan kinerja juga

yangakan dibeli oleh pelanggan. Oleh karena itu, kualitas kinerja pelayanan merupakan dasar bagi pemasaran jasa. Hal tersebut sepaham dengan pendapat

kualitas pelayanan menurut Tjiptono (2007) dimana kualitas pelayanan adalah

upaya pemenuhan kebutuhan dan keinginan pelanggan serta ketepatan penyampaiannya untuk mengimbangi harapan pelanggan.

$$
\text { Kunci utama untuk }
$$

memenangkan persaingan yang ada ialah dengan memberikan nilai dan kepuasan kepada pelanggan melalui penyampaian dan jasa yang berkualitas. Perusahaan dapat memaksimalkan keuntungan dan

memperluas pangsa pasar yang lebih luas dengan mewujudkan kepuasan pelanggan. Tjiptono (2008) mengungkapkan bahwa terciptanya kepuasan pelanggan mampu memberikan beberapa manfaat bagi perusahaan, diantaranya terciptanya hubungan yang harmonis antara pelanggan dan perusahaan, memberikan dasar yang baik bagi pembelian ulang dan loyalitas pelanggan, serta membentuk suatu rekomendasi dari mulut ke mulut (word of mouth) yang baik bagi perusahaan. Tjiptono (2008) juga menyatakan bahwa kepuasan atau ketidakpuasan pelanggan adalah respon pelanggan terhadap evaluasi yang dirasakan antara harapan dan kinerja produk yang dirasakan setelah pemakaian.

Selain faktor kualitas pelayanan, harga merupakan faktor yang sangat penting yang dapat mempengaruhi keputusan pembelian. Harga menurut Kotler dan Amstrong (2001) adalah sejumlah uang yang ditukarkan untuk sebuah produk atau jasa. Namun harga juga dapat menjadi indikator kualitas dimana suatu produk dengan kualitas tinggi akan berani dipatok dengan harga yang tinggi pula. Harga dapat mempengaruhi konsumen dalam mengambil keputusan untuk melakukan pembelian suatu produk.

Dengan semakin banyaknya minat konsumen untuk berbelanja di supermarket saat ini menjadi peluang bisnis yang besar dan menguntungkan bagi

perusahaan. Makadengan terjadinya hal tersebut, kini banyak pengusaha yang

tertarik untuk berkecimpung dalam bidang bisnis yang sama. Hal ini bisa 
dilihat

dengan banyaknya pasar swalayan yang muncul seperti Gardena, Matahari,

Alfa, Indogrosir, Superindo dan sebagainya. Sehingga hal itu, menyebabkan konsumen menjadi sangat selektif dalam memilih tempat untuk berbelanja yang sesuai dengan harapan dan kepuasan yang mereka inginkan.

Nabila swalayan merupakan salah satu swalayan yang terletak di jalan

Imogiri $\mathrm{Km} \mathrm{7,3,} \mathrm{sywalayan} \mathrm{ini} \mathrm{berdiri}$ sejak tahun 2000. Nabila swalayan merupakan salah satu usaha ritel dalam bidang penjualan consumer goods yang dikemas dalam bentuk supermarket dan swalayan. Nabila swalayan mampu

mengembangkan usahanya ditengah semakin ketatnya persaingan dalam bisnis

ritel.Nabila swalayan mempunyai beberapa cabang yang tersebar di berbagai

wilayah di Yogyakarta.

Nabila swalayan mempunyai letak yang strategis, sehingga mudah dijangkau oleh alat transportasi apapun. Retail (eceran) ini memiliki tata ruang yang rapi, nyaman, menawarkan produk yang cukup lengkap dan harga yang ditawarkan sebanding dengan mutu dan kualitas produk yang ditawarkan.Ketika memasuki Nabila swalayan, para pelanggan bisa merasakan keramahan dari para pegawai Nabila swalayan. Untuk itulah Nabila swalayan harus berusaha semaksimal mungkin untuk memberikan pelayanan sesuai dengan yang diinginkan dan dibutuhkan oleh para pelanggan. Pemberian atau pelayanan jasa yang diberikan Nabila swalayan mungkin dapat mengalami kegagalan dalam memberikan kepuasan kepada para pelanggan apabila retail tidak mengetahui bentuk layanan yang sesungguhnya yang diinginkan pelanggan. Persepsi pelanggan terhadap kualitas pelayanan Nabila swalayan mungkin akan memberikan kepuasan terhadap pelanggan yang kemudian akan menciptakan minat bagi pelanggan untuk melakukan pembelian pada swalayan tersebut.

\section{Rumusan Masalah}

Berdasar latar belakang diatas maka permasalahan yang akan dirumuskan pada penelitian ini adalah

1. Apakah variabel kualitas pelayanan, kepuasan dan harga berpengaruh secara parsial terhadap keputusan pembelian pada swalayan Nabila Yogyakarta?

2. Apakah variabel kualitas pelayanan, kepuasan dan harga berpengaruh secara bersama -sama terhadap keputusan pembelian pada swalayan Nabila Yogyakarta?

\section{REVIEW LITERATUR DAN HIPOTESIS}

\section{Landasan Teori \\ Pengertian Jasa}

Jasa adalah setiap tindakan atau kegiatan yang dapat ditawarkan oleh satu pihak kepada pihak lain, pada dasarnya tidak berwujud dan tidak mengakibatkan kepemilikan apapun, poduksinya dapat dikaitkan pada satu produk fisik" ( Kotler, 2012). Dilihat dari tujuannya, pelayanan dibidang jasa mempunyai tujuan yang sama dengan pelayanan produk yaitu memuaskan keinginan dan kebutuhan pelanggan, namun ada beberapa hal perbedaannya,

satu diantaranya terdapat pada proses pembelian, dimana jasa tidak mengakibatkan kepemilikan suatu barang secara fisik, akan tetapi pelanggan 
hanya mendapatkan sesuatu sebagai bukti bahwa jasa tersebut sudah dibeli.

\section{Perilaku Konsumen}

a. Pengertian Perilaku Pelanggan Untuk mempertahankan kelangsungan hidup suatu perusahaan, perilaku konsumen sangat penting karena kelangsungan hidup perusahaan ditentukan oleh keberhasilan dalam memasarkan produk dan kegiatan pemasaran yang sukses itu ditentukan oleh berhasil tidaknya menganalisis perilaku konsumen dan menyesuaikan dengan apa yang menjadi keinginan konsumen.

Perilaku konsumen adalah kegiatan-kegiatan secara langsung terlibat dalam mendapatkan dan mempergunakan barang-barang dan jasa, termasuk didalamnya proses pengambilan keputusan pada persiapan dan penentuan kegiatan-kegiatan tersebut" (Swastha dan Handoko, 2008)

b. Macam-macam Peranan Individu Dalam Perilaku Konsumen

Dalam pengambilan keputusan pembelian barang, konsumen ada lebih dari dua pihak yang terlibat dalam proses pembeliannya. Tiap-tiap individu mempunyai peranan masingmasing dalam pengambilan keputusan pembelian(Tjiptono, 2008)

\section{Kualitas Pelayanan}

Kualitas adalah ciri atau karakteristik suatu barang atau jasa yang berpengaruh pada kemampuannya untuk memuaskan kebutuhan yang dinyatakan maupun yang tersirat. Jelas ini adalah definisi yang berpusat pada pelanggan, pelanggan memiliki kebutuhan dan pengharapan tertentu" (Kotler,2012).

Kualitas memiliki hubungan yang sangat erat dengan kepuasan pelanggan. Kualitas memberikan suatu dorongan kepada pelanggan untuk menjalin ikatan hubungan yang kuat dengan perusahaan sehingga perusahaan dapat meningkatkan kepuasan pelanggan dengan memaksimumkan pengalaman pelanggan yang menyenangkan dan meminimumkan pelanggan yang kurang menyenangkan. Kepuasan pelanggan juga dapat menciptakan kesetiaan atau loyalitas pelanggan kepada perusahaan yang memberikan kualitas memuaskan.

\section{Kepuasan}

Kata kepuasan (satisfaction) berasal dari bahasa Latin "satis" (artinya cukup baik, memadai) dan "facio" (melakukan atau membuat) menurut Tjiptono dan Chandra (2004) sehingga kepuasan bisa diartikan sebagai upaya pemenuhan sesuatu atau membuat sesuatu memadai. Kepuasan pelanggan berbeda dengan kualitas pelayanan, dimana kepuasan merupakan evaluasi spesifik terhadap transaksi pemberi jasa,sedangkan persepsi terhadap kualitas jasa terkait dengan penilaian umum mengenai superioritas pemberi jasa. Kepuasan juga merupakan tingkat perasaan konsumen yang diperoleh setelah konsumen melakukan / menikmati sesuatu. Dengan demikian dapat diartikan kepuasaan konsumen merupakan perbedaan antara yang diharapkan konsumen (nilai harapan) dengan situasi yang diberikan perusahaan di dalam usaha memenuhi harapan konsumen. Menurut Kotler (2012) menyatakan bahwa kepuasan pelanggan adalah perasaan senang atau kecewa seseorang yang muncul setelah membandingkan antara persepsi/ kesannya terhadap kinerja (atau hasil) suatu produk dan harapanharapannya.

\section{Harga}

Harga adalah jumlah uang (ditambah beberapa barang kalau mungkin) yang dibutuhkan untuk mendapatkan sejumlah kombinasi dari barang beserta pelayanannya" (Swastha, 2003)."Harga (price) adalah sejumlah uang yang harus dibayar oleh pelanggan untuk memperoleh produk", (Kotler dan 
Armstrong, 2008). Harga adalah sejumlah uang yang harus dibayarkan konsumen guna memperoleh produk berupa barang dan atau jasa yang dimaksud kepada pihak yang menawarkannya. Harga dalam bentuk nominal uang yang harus dibayarkan telah melalui proses kesepakatan antara kedua belah pihak. Benturan antara kedua kepentingan dan pengaruh harga terhadap kedua belah pihak merupakan proses yang tidak mudah. Kedua hal tersebut tidak bisa dipisahkan karena sama penting dan berpengaruh.

Para eksekutif maupun praktisi pemasaran harus selalu ekstra hati-hati dalam menetapkan harga akhir yang harus dibayarkan oleh konsumen. Hal tersebut sangat sensitif mengingat betapa besarnya pengaruh dan pentingnya harga baik bagi perusahaan maupun pada konsumen. "Penetapan harga terhadap produk harus memperhatikan kesesuaian harga dan tingkat harga", ( Tjiptono, 2008). Kedua indikator tersebut dapat sangat berpengaruh dan menentukan perilaku konsumen dalam pembelian.

\section{Keputusan Pembelian}

Keputusan seorang pembeli juga dipengaruhi oleh ciri-ciri kepribadiannya, termasuk usia, pekerjaan, keadaan ekonomi. Perilaku konsumen akan menentukan proses pengambilan keputusan dalam melakukan pembelian. Menurut Kotler (2012) ada beberapa tahap dalam mengambil suatu keputusan untuk melakukan pembelian.

Pengertian keputusan pembelian, menurut Kotler \& Armstrong (2012) adalah tahap dalam proses pengambilan keputusan pembeli di mana konsumen benar-benar membeli. Pengambilan keputusan merupakan suatu kegiatan individu yang secara langsung terlibat dalam mendapatkan dan mempergunakan barang yang ditawarkan.

\section{Hipotesis}

H1: Kualitas pelayanan, kepuasan dan harga berpengaruh secara parsial

terhadap keputusan pembelian pada swalayan Nabila Yogyakarta.

H2: Kualitas pelayanan, kepuasan dan harga berpengaruh secara bersama sama terhadap keputusan pembelian pada swalayan Nabila Yogyakarta.

\section{METODE PENELITIAN \\ Populasi dan Sampel}

Populasi adalah wilayah generalisasi yang terdiri atas obyek atau subyek yang mempunyai kualitas dan karakteristik tertentu yang ditetapkan oleh penelitian untuk dipelajari dan kemudian ditarik kesimpulannya (Sugiyono, 2009). Populasi penelitian ini adalah seluruh pelanggan swalayan Nabila Yogyakarta.

Sampel adalah sebagian dari jumlah karakteristik yang dimiliki oleh populasi tersebut (Sugiyono, 2009). Menurut Indriantoro (2009) sampel adalah sebagian dari elemen populasi yang dianggap dapat mewakili populasi. Dalam penelitian ini sampel yang digunakan adalah sebagian konsumenswalayan Nabila Yogyakarta

\section{Definisi Operasional}

1. Variabel Independen

Dalam penelitian ini yang menjadi variabel bebas pertama adalah

kualitas pelayanan $\left(\mathrm{X}_{1}\right)$. Ada lima dimensi yang membentuk kualitas pelayanan menurut Menurut Parasuraman (dalam Rambat Lupiyoadi, 2001), Persepsi Kualitas Layanan menurut Parasuraman Parasuraman, A., Zeithaml, V.A. and Berry, L.L. (1991) dalam SERVQUAL: A multiple-item scale for measuring customer perceptions of service quality 
Variabel bebas kedua yaitu kepuasan pelanggan. Kepuasan pelanggan adalah tingkat perasaan seseorang setelah membandingkan kinerja (hasil) yang ia rasakan dibandingkan dengan harapannya. Jadi, kepuasan merupakan fungsi dari persepsi atau kesan atas kinerja dan harapan. Jika kinerja berada dibawah harapan maka pelanggan tidak puas. Jika kinerja memenuhi harapan maka pelanggan akan puas. Jika kinerja melebihi harapan maka pelanggan akan amat puas atau senang (Kotler : 2012).

Variabel bebas ketiga yaitu harga. Harga adalah suatu atribut yang

melekat pada suatu barang yang memungkinkan barang tersebut dapat

memenuhi kebutuhan, keinginan dan memuaskan konsumen.Menurut $\quad M c$ Charty (Swastha, 2010)

\section{Variabel Dependen}

Variabel terikat yaitu keputusan pembelian. Pengertian keputusan pembelian, menurut Kotler \& Armstrong (2012) adalah tahap dalam proses pengambilan keputusan pembeli di mana konsumen benar-benar membeli.

\section{Uji Instrumen}

\section{Uji Validitas}

Validitas adalah instrumen yang dapat digunakan untuk mengukur apa

yang seharusnya dapat diukur (Sugiyono 2009). Validitas digunakan untuk mengetahui kesamaan antara data yang terkumpul dengan data yang sesungguhnya terjadi pada objek yang diteliti, sehingga terdapat data yang valid.
Tipe validitas adalah validitas konstruk (construcy Validity) menentukan validitas alat pengukur dengan mengkorelasikan antara skor yang diperoleh masing-masing item yang berupa pertanyaan atau pernyataan dengan skor totalnya, skor total ini merupakan nilai yang diperoleh dari hasil penjumalahan semua skor item korelasi antara skor item dengan skor totalnya harus signifikan berdasarkan ukuran statistik tertentu. Bila semua item yang disusun berdasarkan dimensi konsep berkorelasi dengan skor totalnya, maka dapat disimpulkan bahwa alat pengukur tersebut mempunyai validitas. Dalam penelitian ini dapat digunakan validitas dengan teknik korelasi Pearson Produk Moment (Sugiyono 2009)

2. Uji Reliabilitas

Uji ini dilakukan untuk mengetahui tingkat konsistensi hasil pengukuran

bila dilakukan pengukuran data dua kali atau lebih gejala yang sama. Hasilnya

ditunjukkan oleh sebuah indeks yang menunjukkan seberapa jauh suatu alat ukur dapat dipercaya. Uji ini diterapkan untuk mengetahui apakah responden telah menjawab pertanyaanpertanyaan secara konsisten atau tidak,sehingga

kesungguhan jawabannya dapat dipercaya. Untuk melihat relibilitas instrumen akan dihitung Alpha Cronbach masing-masing instrumen. Menurut Arikunto variabel dikatakan realibel jika memiliki nilai Alpha Cronbach> 0,60 dengan rumus Cronbach's Alpha Coefficient (Arikunto, 2002). 
Teknik Analisis Data

1. Analisis Regresi Berganda

$\mathrm{Y}=\mathrm{a}+\mathrm{b} 1 \mathrm{X} 1+\mathrm{b} 2 \mathrm{X} 2+\mathrm{b} 3 \mathrm{X} 3+\mathrm{e}$

Keterangan :

$\mathrm{Y}=$ keputusan pembelian(variabel terikat)

$\mathrm{X} 1=$ Kualitas pelayanan $($ variabel bebas)

$\mathrm{X} 2$ = kepuasan(variabel bebas)

$\mathrm{X} 3$ = harga (variabel bebas)validitas dengan teknik korelasi Pearson Produk Moment (Sugiyono 2009)

\section{Uji Hipotesis}

1. Uji Parsial (Uji T)

Hipotesis II untuk mengetahui apakah kualitas pelayanan, kepuasan dan hargaberpengaruh secara parsial terhadap keputusan pembelian( $(Y)$, maka pengujian melalui uji t, yaitu dengan membandingkan t-hitung (th) dengan t- tabel ( $\mathrm{t}_{t}$ ) pada derajat signifikan $95 \%(\alpha=0,05)$.

2. Uji Simultan (Uji F)

Hipotesis 1 untuk mengetahui apakah kualitas pelayanan, kepuasan dan harga berpengaruh secara serempak terhadap keputusan pembelian (Y), Maka menggunakan uji $F$, yaitu dengan menguji koefisien Regresi Linier Berganda secara serentak.

3. Uji Koefisien Determinasi

Dari koefisien determinan $\left(R_{2}\right)$ dapat diketahui derajat ketepatan dari analisis Regresi Linear Berganda. $\mathrm{R}_{2}$ menunjukkan besarnya variasi sumbangan seluruh variabel bebas dan variabel terikatnya.

\section{HASIL PENELITIAN DAN PEMBAHASAN}

\section{Hasil Analisis Responden} Jenis Kelamin
Tabel 4.1

\begin{tabular}{c|c|c}
\multicolumn{3}{c}{ Identitas Responden Berdasarkan Jenis Kelamin } \\
\hline Jenis Kelamin & Frekuensi & Persentase (\%) \\
\hline Laki-laki & 47 & 47.0 \\
\hline Perempuan & 53 & 53.0 \\
\hline Jumlah & 100 & 100,0 \\
\hline Sumber: data diolah, 2014
\end{tabular}

Berdasarkan Tabel 4.1, dapat dilihat bahwa mayoritas responden adalah perempuan yaitu sebanyak 53 orang (53\%) dan laki - laki yaitu sebanyak 47 orang (47\%).

Usia

Tabel 4.2

Identitas Responden Berdasarkan Usia
\begin{tabular}{|c|c|c|}
\hline Usia & Frekuensi & Persentase (\%) \\
\hline $17 \mathrm{~s} / \mathrm{d} 25$ tahun & 21 & 21.0 \\
\hline $26 \mathrm{~s} / \mathrm{d} 34$ tahun & 36 & 36.0 \\
\hline $35 \mathrm{~s} / \mathrm{d} 43$ tahun & 25 & 25.0 \\
\hline $44 \mathrm{~s} / \mathrm{d} 50$ tahun & 18 & 18.0 \\
\hline Jumlah & 100 & 100,0 \\
\hline Sumber: data diolah, 2014
\end{tabular}

Berdasarkan Tabel 4.2, dapat dilihat bahwa mayoritas responden berusia $26 \mathrm{~s} / \mathrm{d} 34$ tahun yaitu sebanyak 36 orang (36\%), diikuti usia 35 s/d 43 tahun sebanyak 25 orang (25\%), kemudian usia $17 \mathrm{~s} / \mathrm{d} 25$ tahun sebanyak 21 orang $(21 \%)$, dan sisanya sebanyak 18 orang (18\%) berusia 44 s/d 50 tahun.

Tabel 4.3

Identitas Responden Berdasarkan Penghasilan

\begin{tabular}{|c|c|c|}
\hline Penghasilan & Frekuensi & Persentase (\%) \\
\hline < Rp. 1.000.000 & 19 & 19.0 \\
\hline Rp. 1.000.001 s/d Rp. 2.000 .000 & 27 & 27.0 \\
\hline Rp. 2.000.001 s/d Rp. 3.000.000 & 31 & 31.0 \\
\hline Rp. 3.000.001 s/d Rp. 4.000.000 & 12 & 12.0 \\
\hline > Rp.4.000.000 & 11 & 11.0 \\
\hline Jumlah & 100 & 100,0 \\
\hline Sumber: data diolah, 2014
\end{tabular}

Berdasarkan Tabel 4.3, dapat dilihat bahwa mayoritas responden berpenghasilan Rp. 2.000.001 s/d Rp. 3.000 .000 per bulan yaitu sebanyak 31 orang (31\%), diikuti penghasilan $\mathrm{Rp}$. 1.000.001 s/d Rp. 2.000.000 sebanyak 27 orang (27\%), kemudian penghasilan Rp. < Rp. 1.000.000 sebanyak 19 orang (19\%), dan 
sisanya sebanyak 11 orang (11\%) berpenghasilan > Rp.4.000.000 per bulan.

\section{Pekerjaan}

Tabel 4.4

Identitas Responden Berdasarkan Pekerjaan

\begin{tabular}{|c|c|c|}
\hline Pekerjaan & Frekuensi & $\begin{array}{c}\text { Persentase } \\
\text { (\%) }\end{array}$ \\
\hline Pelajar / Mahasiswa & 9 & 9.0 \\
\hline Pegawai Swasta & 39 & 39.0 \\
\hline Pegawai Negeri Sipil (PNS) & 17 & 17.0 \\
\hline ibu rumah tangga & 24 & 24.0 \\
\hline Lain-lain & 11 & 11.0 \\
\hline Jumlah & 100 & 100,0 \\
\hline Sumber: data diolah, 2014 & \multicolumn{2}{|l}{}
\end{tabular}

Berdasarkan Tabel 4.4, dapat dilihat bahwa mayoritas responden bekerja sebagai Pegawai Swasta yaitu sebanyak 39 orang (39\%), diikuti bekerja sebagai ibu rumah tangga sebanyak 24 orang (24\%), kemudian bekerja sebagai Pegawai Negeri Sipil (PNS) sebanyak 17 orang (17\%), kemudian bekerja Lain-lain sebanyak 11

orang (11\%), dan sisanya sebanyak 9 orang (9\%) sebagai Pelajar / Mahasiswa.

\section{Deskripsi Variabel Penalitian Kualitas Layanan}

Tabel 4.5

Deskripsi Variabel Kualitas Layanan

\begin{tabular}{|c|l|c|c|}
\hline Interval & \multicolumn{1}{|c|}{ Kategori } & Frekuensi & $\begin{array}{c}\text { Persentase } \\
\mathbf{( \% )}\end{array}$ \\
\hline $1,00-1,79$ & Sangat rendah & 0 & 0,0 \\
\hline $1,80-2,59$ & Rendah & 3 & 3.0 \\
\hline $2,60-3,39$ & Cukup & 30 & 30.0 \\
\hline $3,40-4,19$ & Tinggi & 62 & 62.0 \\
\hline $4,20-5,00$ & Sangat tinggi & 5 & 5.0 \\
\hline \multicolumn{2}{|c|}{ Jumlah } & 100 & 100,0 \\
\hline Rata - rata = 3,5186 & & \\
\hline
\end{tabular}

Berdasarkan Tabel 4.5, dapat dilihat bahwa dari 100 responden yang memberi tanggapan terhadap itemitem pernyataan variabel Kualitas Layanan, tidak ditemukan orang $(0 \%)$ memiliki Kualitas Layanan yang tergolong "sangat rendah", 3 orang $(3,0 \%)$ tergolong "rendah", 30 orang $(30 \%)$ tergolong "cukup", 62 orang $(62,0 \%)$ tergolong "tinggi" dan 5 responden $(5 \%)$ tergolong "sangat tinggi". Kepuasan rata-rata diperoleh sebesar 3,5186. Kepuasan ini berada dalam rentang 3,40 - 4,19 yang berarti "tinggi". Ini menunjukkan bahwa tingkat Kualitas Layanan pelanggan Swalayan Nabila Yogyakarta tergolong tinggi.

\section{Kepuasan}

Tabel 4.6

Deskripsi Variabel Kepuasan

\begin{tabular}{|c|l|c|c|}
\hline Interval & \multicolumn{1}{|c|}{ Kategori } & Frekuensi & $\begin{array}{c}\text { Persentase } \\
\mathbf{( \% )}\end{array}$ \\
\hline $1,00-1,79$ & Sangat rendah & 3 & 3.0 \\
\hline $1,80-2,59$ & Rendah & 24 & 24.0 \\
\hline $2,60-3,39$ & Cukup & 68 & 68.0 \\
\hline $3,40-4,19$ & Tinggi & 5 & 5.0 \\
\hline $4,20-5,00$ & Sangat tinggi & 100 & 100,0 \\
\hline \multicolumn{2}{|c|}{ Jumlah } & & \\
\hline \multicolumn{2}{|r|}{ Rata - rata $=\mathbf{2 , 7 2 6 7}$} &
\end{tabular}

Berdasarkan Tabel 4.6, dapat dilihat \ bahwa dari 100 responden yang memberi tanggapan terhadap item-item pernyataan variabel Kepuasan, ditemukan 3 responden (3\%) yang memiliki Kepuasan yang tergolong "sangat rendah", 24 orang $(24 \%)$ tergolong "rendah", 68 orang $(68 \%)$ tergolong "cukup", 5 orang $(5 \%)$ tergolong "tinggi" dan tidak ada orang $(0 \%)$ tergolong "sangat tinggi". Kepuasan rata rata diperoleh sebesar 2,7267 . Kepuasan ini berada dalam rentang 2,60 - 3,39 yang berarti "cukup tinggi". Ini menunjukkan bahwa Kepuasan pelanggan Swalayan Nabila Yogyakarta tergolong cukup tinggi. 
Harga

Iabel 4.1

Deskripsi Variabel Harga

\begin{tabular}{|c|l|c|c|}
\hline Interval & \multicolumn{1}{|c|}{ Kategori } & Frekuensi & $\begin{array}{c}\text { Persentase } \\
\mathbf{( \% )}\end{array}$ \\
\hline $1,00-1,79$ & Sangat rendah & 0 & 0,0 \\
\hline $1,80-2,59$ & Rendah & 4 & 4,0 \\
\hline $2,60-3,39$ & Cukup & 29 & 29,0 \\
\hline $3,40-4,19$ & Tinggi & 51 & 51,0 \\
\hline $4,20-5,00$ & Sangat tinggi & 16 & 16,0 \\
\hline \multicolumn{2}{|c|}{ Jumlah } & 100 & 100,0 \\
\hline \multicolumn{2}{|c|}{ Rata - rata $=\mathbf{3 , 5 4 6 0}$} & & \\
\hline
\end{tabular}

Berdasarkan Tabel 4.7, dapat dilihat bahwa dari 100 responden yang memberi tanggapan terhadap itemitem pernyataan variabel Harga, ditemukan 0 orang $(0 \%)$ menyatakan harga cocok "sangat rendah", 4 orang $(4,0 \%)$ menyatakan harga cocok "rendah", 29 orang (29,0\%) menyatakan harga cocok "cukup", 51 orang $(51,0 \%)$ menyatakan harga cocok "tinggi" dan 16 orang $(16,0 \%)$ menyatakan harga cocok "sangat tinggi". menyatakan harga cocok ratarata 50 diperoleh sebesar 3,5460. Kepuasan ini berada dalam rentang 3,40 - 4,19 yang berarti "tinggi". Ini menunjukkan bahwa Harga Swalayan Nabila Yogyakarta tergolong sesuai dengan keinginan konsumen.

\section{Keputusan Pembelian}

$$
\text { Tabel } 4.8
$$

Deskripsi Variabel Keputusan pembelian

\begin{tabular}{|c|l|c|c|}
\hline Interval & \multicolumn{1}{|c|}{ Kategori } & Frekuensi & $\begin{array}{c}\text { Persentase } \\
\mathbf{( \% )}\end{array}$ \\
\hline $1,00-1,79$ & Sangat rendah & 9 & 9,0 \\
\hline $1,80-2,59$ & Rendah & 43 & 43,0 \\
\hline $2,60-3,39$ & Cukup & 40 & 40,0 \\
\hline $3,40-4,19$ & Tinggi & 8 & 8,0 \\
\hline $4,20-5,00$ & Sangat tinggi & 0 & 0,0 \\
\hline \multicolumn{2}{|c|}{ Jumlah } & 100 & 100,0 \\
\hline Rata - rata $=\mathbf{2 , 4 9 8 0}$ & & \\
\hline Sumber: data diolah, 2014 &
\end{tabular}

Berdasarkan Tabel 4.8, dapat dilihat bahwa dari 100 responden yang memberi tanggapan terhadap itemitem pernyataan variabel Keputusan pembelian, ditemukan 9 responden (9\%) memiliki Keputusan pembelian yang tergolong "sangat rendah", 43 orang (43\%) tergolong "rendah", 40 orang (40,0\%) tergolong "cukup", 8 orang $(8 \%)$ tergolong "tinggi" dan tidak ada orang $(0 \%)$ tergolong "sangat loyal". Kepuasan rata-rata diperoleh sebesar 2,4980. Kepuasan ini berada dalam rentang 1,80 - 2,59 yang berarti "rendah". Ini menunjukkan bahwa tingkat Keputusan pembelian pelanggan

Swalayan Nabila Yogyakarta tergolong rendah.

\section{Hasil Penelitian}

1. Hasil Uji Validitas

\begin{tabular}{|c|c|c|c|c|c|c|c|}
\hline Item & $\mathbf{r}_{\text {hittung }} 30$ resp & kriteria & keterangan & Item & $\begin{array}{c}\mathbf{r}_{\text {hitumg }} 30 \\
\text { resp }\end{array}$ & kriteria & keterangan \\
\hline$x 1.1 .1$ & $0,793^{* *}$ & 0,361 & valid & $\mathrm{x} 2.1$ & $0,684^{* *}$ & 0,361 & valid \\
\hline$x 1.1 .2$ & $0,841^{* *}$ & 0,361 & valid & $\mathrm{x} 2.2$ & $0,850^{* *}$ & 0,361 & valid \\
\hline $\begin{array}{ll}x 1.1 .3 \\
\end{array}$ & $0,753^{* *}$ & 0,361 & valid & $\times 2.3$ & $0,901^{* *}$ & 0,361 & valid \\
\hline $\begin{array}{l}x 1.1 .4 \\
\end{array}$ & $0,751^{* *}$ & 0,361 & valid & $\mathrm{x} 3.1$ & $0,921^{* *}$ & 0,361 & valid \\
\hline $\begin{array}{l}x 1.2 .1 \\
\end{array}$ & $0,728^{* *}$ & 0,361 & valid & $\mathrm{x} 3.2$ & $0,835^{* *}$ & 0,361 & valid \\
\hline$x 1.2 .2$ & $0,773^{* *}$ & 0,361 & valid & $x 3.3$ & $0,883^{* *}$ & 0,361 & valid \\
\hline $\mathrm{x} 1.2 .3$ & $0,837^{* *}$ & 0,361 & valid & $\times 3.4$ & $0,860^{* *}$ & 0,361 & valid \\
\hline $\begin{array}{ll}\mathrm{x} 1.2 .4 \\
\end{array}$ & $0,847^{* *}$ & 0,361 & valid & $\times 3.5$ & $0,533^{* *}$ & 0,361 & valid \\
\hline$x 1.2 .5$ & $0,482^{* *}$ & 0,361 & valid & $\mathrm{y1}$ & $0,593^{* *}$ & 0,361 & valid \\
\hline$x 1.3 .1$ & $0,773^{* *}$ & 0,361 & valid & $y 2$ & $0,656^{* *}$ & 0,361 & valid \\
\hline $\begin{array}{l}x 1.3 .2 \\
\end{array}$ & $0,845^{* *}$ & 0,361 & valid & $\mathrm{y}^{3}$ & $0,764^{* *}$ & 0,361 & valid \\
\hline $\begin{array}{l}x 1.3 .3 \\
\end{array}$ & $0,808^{* *}$ & 0,361 & valid & $\mathrm{y} 4$ & $0,802^{* *}$ & 0,361 & valid \\
\hline$x 1.3 .4$ & $0,723^{* *}$ & 0,361 & valid & y5 & $0,786^{* *}$ & 0,361 & valid \\
\hline \begin{tabular}{ll|}
$x 1.4 .1$ \\
\end{tabular} & $0,821^{* *}$ & 0,361 & valid & & & & \\
\hline$x 1.4 .2$ & $0,832^{* *}$ & 0,361 & valid & & & & \\
\hline $\begin{array}{l}x 1.4 .3 \\
\end{array}$ & $0,922^{* *}$ & 0,361 & valid & & & & \\
\hline $\begin{array}{ll}x 1.4 .4 \\
\end{array}$ & $0,841^{* *}$ & 0,361 & valid & & & & \\
\hline $\begin{array}{l}x 1.5 .1 \\
\end{array}$ & $0,806^{* *}$ & 0,361 & valid & & & & \\
\hline $\begin{array}{l}\mathrm{x} 1.5 .2 \\
\end{array}$ & $0,845^{* *}$ & 0,361 & $\begin{array}{l}\text { Valid } \\
\end{array}$ & & & & \\
\hline $\begin{array}{l}x 1.5 .3 \\
\end{array}$ & $0,656^{* *}$ & 0,361 & Valid & & & & \\
\hline $\begin{array}{l}\mathrm{x} 1.5 .4 \\
\end{array}$ & $0,801^{* *}$ & 0,361 & Valid & & & & \\
\hline$x 1.5 .5$ & $0,545^{* *}$ & 0,361 & Valid & & & & \\
\hline
\end{tabular}

Berdasarkan hasil uji validitas instrumen variabel Keputusan pembelian pada Tabel 4.9, menunjukkan bahwa semua item memiliki koefisien korelasi ( $r_{\text {hitung }}$ lebih besar dari $r_{\text {tabel }}=0,361$ yang berarti valid. 
2. Hasil Uji Reliabilitas

Tabel 4.10

Hasil Uji Reliabilitas Instrumen

\begin{tabular}{|l|c|c|c|}
\hline \multicolumn{1}{|c|}{ Variabel } & $\begin{array}{c}\text { Cronbach's } \\
\text { Alpha 30 resp }\end{array}$ & Kriteria & Keterangan \\
\hline $\mathrm{X} 1$ & 0,878 & $\geq 0,60$ & Reliabel \\
\hline $\mathrm{X} 2$ & 0,749 & $\geq 0,60$ & Reliabel \\
\hline $\mathrm{X} 3$ & 0,870 & $\geq 0,60$ & Reliabel \\
\hline $\mathrm{Y}$ & 0,770 & $\geq 0,60$ & Reliabel \\
\hline
\end{tabular}

Hasil pengujian reliabilitas pada Tabel 4.10 menunjukkan bahw koefisien reliabilitas Cronbach's Alpha masing masing variabel lebih besar dari 0,60 yang berarti reliable.

3. Hasil Uji Regresi Linier Berganda

Tabel 4.11

Hasil Estimasi Regresi Linier Bergand

\begin{tabular}{|l|c|c|c|c|}
\hline \multicolumn{1}{|c|}{$\begin{array}{c}\text { Variabel } \\
\text { Independen }\end{array}$} & $\begin{array}{c}\text { Koef. } \\
\text { Regresi }\end{array}$ & $\mathbf{t}_{\text {hitung }}$ & $\mathbf{p}$ & Keputusan \\
\hline Konstanta & $-0,813$ & & & - \\
\hline Kualitas Layanan $\left(\mathrm{X}_{1}\right)$ & 0,409 & 3,351 & 0,001 & Signifikan \\
\hline Kepuasan $\left(\mathrm{X}_{2}\right)$ & 0,249 & 2,466 & 0,015 & Signifikan \\
\hline Harga $\left(\mathrm{X}_{3}\right)$ & 0,336 & 3,751 & 0,000 & Signifikan \\
\hline Variabel dependen: Keputusan pembelian (Y) \\
$\quad=0,359$ \\
$\mathrm{R}^{2} \quad=17,961$ \\
$\mathrm{~F}_{\text {himang } \quad=0,000}$ \\
$\mathrm{p} \quad=$ \\
Sumber: data diolah, 2014
\end{tabular}

Berdasarkan hasil analisis regresi linier berganda pada Tabel 4.11 diperoleh persamaan regresi sebagai berikut: $Y=-0,813+0,409 X_{1}+0,249 X_{2}+$ $0,336 \mathrm{X}_{3}+\mathrm{e}$

a. Konstanta (a)

Pada persamaan diperoleh konstanta sebesar $-0,813$ (negatif) yang berarti bahwa jika skor pada ketiga variabel Kualitas Layanan, Kepuasan dan Harga sama dengan nol maka
Keputusan pembelian akan turun sebesar 0,813.

b. Koefisien Regresi Kualitas Layanan

Koefisien regresi Kualitas Layanan diperoleh sebesar 0,409 (positif) yang berarti bahwa apabila skor pada variabel Kualitas Layanan meningkat 1 maka Keputusan pembelian akan meningkat sebesar 0,409 dan sebaliknya, dengan asumsi variabel Kepuasan sama dan dan Harga dengan nol atau dalam keadaan konstan.

c. Koefisien Regresi Kepuasan (b2) Koefisien regresi Kepuasan diperoleh sebesar 0,249 (positif) yang berarti bahwa apabila skor pada variabel Kepuasan meningkat

maka Keputusan pembelian akan meningkat sebesar 0,249 dan sebaliknya, dengan asumsi variabel Kualitas Layanan dan Harga sama dengan nol atau dalam keadaan konstan.

d. Koefisien Regresi Harga (b3) Koefisien regresi Harga diperoleh sebesar 0,336 (positif) yang berarti bahwa apabila skor pada variabel Harga meningkat 1 maka Keputusan pembelian akan meningkat sebesar 0,336 dan sebaliknya, dengan asumsi variabel Kualitas Layanan dan Kepuasan sama dengan nol atau dalam keadaan konstan.

4. Hasil Uji Parsial (Uji T)

Pengaruh Variabel Kualitas Layanan terhadap Keputusan pembelian Pelanggan

Dari hasil perhitungan pada Tabel 4.8 diperoleh koefisien regresi Kualitas Layanan sebesar 0,409 (positif). Uji signifikansi koefisien ini dengan $t$ statistik diperoleh thitung sebesar sebesar 3,351 dan 
probabilitas kesalahan $(p)=0,001$. tabel dengan $\mathrm{db}=\mathrm{N}-\mathrm{k}=100-4=$ 96, pada taraf signifikan 0,05 diperoleh sebesar 1,985. Karena thitung $>$ tabel $(3,351>1,985)$ dan $p<$ 0,05, maka $\mathrm{H}_{0}$ ditolak dan sebaliknya $\mathrm{H}_{\mathrm{a}}$ diterima. Jadi dapat disimpulkan bahwa secara parsial variabel Kualitas Layanan berpengaruh positif dan signifikan terhadap Keputusan pembelian pelanggan Swalayan Nabila Yogyakarta.

\section{Pengaruh Variabel Kepuasan terhadap Keputusan pembelian Pelanggan}

Dari hasil perhitungan pada Tabel 4.8 diperoleh koefisien regresi Kepuasan sebesar 0,249 (positif). Uji signifikansi koefisien diperoleh thitung sebesar sebesar 2,466 dan $p=$ 0,015. Karena thitung > ttabel $(2,466>1,985)$ dan $p<0,05$, maka $\mathrm{H}_{0}$ ditolak dan sebaliknya $\mathrm{H}_{\mathrm{a}}$ diterima. Jadi dapat disimpulkan bahwa secara parsial variabel Kepuasan berpengaruh positif dan signifikan terhadap Keputusan pembelian pelanggan Swalayan Nabila Yogyakarta.

Pengaruh Variabel Harga terhadap Keputusan pembelian Pelanggan

Dari hasil perhitungan pada Tabel 4.8 diperoleh koefisien regresi Harga sebesar 0,336 (positif). Uji signifikansi koefisien diperoleh thitung sebesar sebesar 3,751 dan $p=$ 0,000 . Karena thitung $>$ tabel $(3,751>$ 1,985) dan $\mathrm{p}>0,05$, maka $\mathrm{H}_{0}$ ditolak dan sebaliknya $\mathrm{H}_{\mathrm{a}}$ diterima. Jadi dapat disimpulkan bahwa secara parsial variabel Harga berpengaruh positif dan signifikan terhadap Keputusan pembelian pelanggan Swalayan Nabila Yogyakarta

5. Hasil Uji Simultan (Uji F)
Berdasarkan Tabel 4.13, uji signifikansi pengaruh Kualitas Layanan, Kepuasan dan Harga pelanggan secara bersama sama terhadap Keputusan pembelian konsumen, dengan $F$ statistik diperoleh $F_{\text {hitung sebesar 17,961 dan }}$ probabilitas kesalahan $(p)=0,000$, pada taraf signifikansi 0,05 dan $p<$ 0,05 maka $\mathrm{H}_{0}$ ditolak dan sebaliknya $\mathrm{H}_{\mathrm{a}}$ diterima. Jadi dapat disimpulkan bahwa variabel Kualitas Layanan, Kepuasan dan Harga pelanggan secara bersamasama berpengaruh signifikan terhadap Keputusan pembelian konsumen pada Swalayan Nabila Yogyakarta.

6. Hasil Uji Koefisien Determinasi

Ditemukan pula koefisien determinasi $\left(R_{2}\right)$ sebesar 0,359 yang berarti bahwa sekitar 35,9\% variasi pada variabel Keputusan pembelian mampu dijelaskan oleh variabel Kualitas Layanan, Kepuasan dan Harga pelanggan secara bersama-sama. Sedangkan sisanya yaitu sebesar $64,1 \%$ diterangkan oleh variasi lain di luar model, seperti keterlibatan konsumen, promosi, dan lain sebagainya.

\section{Pembahasan}

Secara parsial, ditemukan bahwa Kualitas Layanan berpengaruh positif dan signifikan terhadap Keputusan pembelian pelanggan yang merasakan kualitas yang diterima sesuai dengan Harga yang harus dibayar, produk yang sesuai dengan kebutuhan, dan evaluasi atas kehandalan membuat pelanggan tidak ingin beralih pada swalayan lain, pelanggan akan memaklumi kesalahan dan bahkan pelanggan bersedia merekomendasikan kepada orang lain. Ini berarti bahwa meningkatnya Kualitas Layanan akan meningkatkan Keputusan pembelian 
pelanggan dan sebaliknya,
menurunnya

Kualitas Layanan akan menurunkan Keputusan pembelian pelanggan. ini Hasil penelitian mendukung pendapat yang dikemukakan Kotler (2012) iklan pada dasarnya bertujuan untuk memperkenalkan, mengingatkan, mengajak dan menjaga hubungan dengan konsumen akan tertarik pada produk yang ditawarkan, serta salah satu tugas komunikasi spesifik dan level keberhasilan

yang harus dicapai atas audiens spesifik pada periode waktu yang spesifik. Pesan yang disampaikan dalam iklan harus mampu menarik perhatian, mempertahankan ketertarikan, membangkitkan keinginan, dan menggerakkan tindakan, sehingga Kepuasan dapat terbentuk dibenak konsumen disaat konsumen mengenal, memakai produk. Konsumen yang puas akan membeli kembali produk, memuji produk yang dibelinya dihadapan orang lain dan sedikit menaruh perhatian pada merek pesaing. Maka hal ini akan sangat menguntungkan sekali bagi perusahaan karena konsumen tersebut akan cenderung loyal.

Secara parsial, Kepuasan berpengaruh positif dan signifikan terhadap Keputusan pembelian pelanggan yang memiliki Kepuasan atas informasi yang didapat, Kepuasan perusahaan akan menanggapi keluhan, dan Kepuasan terpenuhinya janji perusahaan membuat pelanggan tidak ingin beralih pada swalayan lain, pelanggan akan memaklumi kesalahan dan bahkan pelanggan bersedia merekomendasikan kepada orang lain. Ini berarti bahwa meningkatnya Kepuasan akan meningkatkan Keputusan pembelian pelanggan dan sebaliknya, menurunnya Kepuasan akan menurunkan Keputusan pembelian pelanggan. ini Hasil penelitian mendukung penelitan Norman, 1991 dalam Kadampully dan Suhartanto, (2000) yang berkesimpulan bahwa untuk menghindari risiko yang besar, konsumen lebih suka membeli dari penyedia-penyedia barang atau jasa yang memiliki citra baik (Norman, 1991 dalam Kadampully dan Suhartanto, 2000)

\section{KESIMPULAN DAN SARAN}

\section{Kesimpulan}

Berdasarkan hasil analisis pada Bab IV maka dapat ditarik beberapa simpulan sebagai berikut: 1. Kualitas Layanan mempunyai pengaruh

positif dan signifikan terhadap Keputusan pembelian pelanggan Swalayan NabilaYogyakarta, variabel Kepuasan mempunyai pengaruh positif dan signifikan terhadap keputusan pembelian pelanggan Swalayan Nabila Yogyakarta, variabel harga mempunyai pengaruh positif dan signifikan terhadap keputusan pembelian pelanggan Swalayan Nabila Yogyakarta.

2. Variabel Kualitas Layanan, Kepuasan dan harga konsumen berpengaruh secara serempak terhadap Keputusan pembelian pelanggan pada pengguna Swalayan Nabila Yogyakarta.

\section{Saran}

Berdasarkan kesimpulan diatas, maka selanjutnya dapat diusulkan saran yang bermanfaat yang berkaitan dengan pengaruh Kualitas Layanan, Kepuasan dan Harga pada Swalayan Nabila Yogyakarta maka sebaiknya agar manajemen perusahaan dapat meningkatkan kualitas produk yang diberikan kepada pelanggan dan selalu mengevaluasi produk yang 
dikeluarkan hingga mencapai kehandalan produk tersebut. Swalayan Nabila Yogyakarta harus tetap mempertahankan Kepuasan pelanggan karena terbukti pada hasil penelitian bahwa Kepuasan pelanggan terhadap Swalayan Nabila Yogyakarta tinggi atas informasi yang diberikan Swalayan Nabila Yogyakarta, dengan demikian Keputusan pembelian pelanggan dapat dipertahankan.

\section{DAFTAR PUSTAKA}

Arikunto, Suharsimi, (2002). Prosedur Penelitian, Suatu Pendekatan Praktek. Jakarta: PT. Rineka Cipta.

Gujarati, Damodar N. 2003. Basic Econometrics. Fourth Edition. New York: McGraw-Hill, Inc

Hair, J. F., Black., W. C., Babin, B. J., Anderson R.E., \& Tatham R. L., 2006. Multivariate Data Analisys. Sixth Edition. New Jersey: Prentice Hall.

Ghozali Imam, Akt, 2005, Aplikasi Analisis Multivariate dengan Program SPSS, Badan Penerbit Universitas Diponegoro, Semarang.

Indriantoro Nur dan Bambang Supomo, 2002, Metodologi Penelitian Bisnis, Cetakan Kedua, BPFE, Yogyakarta.

Kotler, Philip, 2012, Manajemen Pemasaran, Edisi Millenium, Pearson Education Asia Pte. Ltd dan PT. Prentihalindo, Jakarta

Kotler, Philip, 2007, Manajemen Pemasaran Perspektif Asia, Alih Bahasa :

Benyamin Molan,Edisi Pertama Bahasa Indonesia, Andi and Pearson Education Asia Pte. Ltd, Yogyakarta.
Kotler, Philip, 2006, Manajemen Pemasaran, Edisi Millenium, Pearson Education Asia Pte. Ltd dan PT. Prentihalindo, Jakarta.

Kotler, Philip Dan Gary Amstrong, 2001, Prinsip-prinsip Pemasaran, Alih Bahasa : Damos Sihombing, Jilid Pertama, Edisi Kedelapan, Erlangga, Jakarta.

Lupiyoadi, Rambat, 2001, Manajemen Pemasaran Jasa, Edisi Pertama, Salemba Empat, Jakarta.

Parasuraman, A., Zeithaml, V.A. and Berry, L.L., 1991 SERVQUAL: A multipleitem scale for measuring customer perceptions of service quality. Journal of Retailing.

Peter, J, Paul dan Olson, 2000, Perilaku Konsumen dan Strategi Pemasaran. Edisi 4, jilid 1. Erlangga, Jakarta

Saifudin Aswar, 2003, Reliabilitas dan Validitas, Edisi Ketiga, Cetakan Kedua, Pustaka Pelajar, Yogyakarta.

Sigit, Soehardi 2003, Pengantar Metode Penelitian Sosial-Bisnis-Manajemen, Cetakan Ketiga, BPFE UST, Yogyakarta.

Sugiarto, 2005, Teknik Sampling, Cetakan Kedua, PT. Gramedia Pustaka Utama, Jakarta. 6667

Sugiyono, 2009, Metode Penelitian Bisnis, Cetakan Kelima, CV. Alfa Beta, Bandung.

Swastha, Basu Dharmesta dan Irawan, 2000, Manajemen Pemasaran Modern, Edisi Kedua, Cetakan Ketiga, Penerbit Liberty, Yogyakarta.

Swastha , Basu dan T. Hani Handoko, 2000, Manajemen Pemasaran 
(Analisa Perilaku Konsumen), Edisi Pertama BPFE, Yogyakarta.

Swastha, Basu 2003. Manajemen Pemasaran Modern, edisi kedua, Yogyakarta, Liberty

Tjiptono, Fandy, 2002, Manajemen Jasa, Edisi Kedua, Cetakan Ketiga, Penerbit Andi, Yogyakarta.

Tjiptono, Fandy 2002, Strategi Pemasaran, Andy Offset, Yogyakarta

Tjiptono, Fandy 2007, Strategi Pemasaran. Edisi ke dua, penerbit Andi,. Yogyakarta.

Tjiptono, Fandy 2008, Strategi Bisnis Pemasaran. Andi. Yogyakarta

Tjiptono, Fandy. 2006. Pemasaran Jasa, Edisi Pertama, Cetakan Kedua, Malang: Penerbit Bayumedia Publishing.

Tjiptono, F,Chandra, G. Chandra, Y.,2004. Pemasaran Global Internasionalisasi dan Internetisasi. Yogyakakarta : Penerbit Andi. 